\title{
The Problems and Countermeasures of Tourism Development of Intangible Cultural Heritage in Harbin
}

\author{
Qiang Yu ${ }^{1, a}$, Lanlan Liu',b \\ ${ }^{1}$ Harbin University Harbin China \\ ayuqiang0708@163.com, bliulanlan_001@163.com
}

Keywords: Problems and countermeasures, Intangible cultural heritage, Tourism development.

\begin{abstract}
Intangible cultural heritage embodies the wisdom of human development and is an important tourism resource. This paper has combed the status quo of intangible cultural heritage in Harbin, and through the analysis of the existing problems of intangible cultural tourism in Harbin, further expounds the Countermeasures for the development of intangible cultural cultural tourism in Harbin in the future, which is conducive to the development of intangible cultural cultural heritage tourism in Harbin.
\end{abstract}

\section{哈尔滨市非物质文化遗产旅游开发存在的问题及对策分析}

\author{
于强 $1, a$,刘岗岗 $1, b$ \\ 1哈尔滨学院, 哈尔滨, 中国 \\ ayuqiang0708@163.com, bliulanlan_001@163.com
}

关键词：问题及对策; 非物质文化遗产; 旅游开发

中文摘要. 非物质文化遗产凝聚了人类发展的智慧, 是重要的旅游资源。本论文梳理了哈尔 滨市非物质文化遗产现状, 同时通过对哈尔滨市的非物质文化旅游存在的问题进行分析, 进 一步阐述了未来哈尔滨市发展非物质文化旅游的对策, 有利于促进哈尔滨市非物质文化遗产 旅游的开发。

\section{1. 哈尔滨市非物质文化遗产旅游开发现状}

哈尔滨市于1994年被国家批准为历史文化名城，其历史悠久，源远流长。哈尔滨市非物 质文化遗产数量丰富, 哈尔滨市从2008年至2014年, 先后进行了四批非物质文化遗产的申报 和评定工作, 现有非遗名录 131 项, 国家级名录3项, 省级名录53项, 代表传承人99人, 保护 单位 44 个。哈尔滨市非物质文化遗产涉及了旅游资源中的文学、音乐、舞蹈、杂技与竞技等 十个种类, 是哈尔滨市发展旅游业重要资源。文化游因其依托于旅游文化性的本质, 能够满 足人们求新、求知的心理需要, 因此通过把非物质文化表演艺术类遗产加工成为舞台形式、 工艺品等丰富的形式展示给游客, 将具有重大的旅游吸引力。哈尔滨市在非物质文化遗产旅 游方面做了积极的尝试并取得一定的成效。从开发的形式来看涵盖了非物质文化旅游开发的 所有形式, 其中中华巴洛克、关东古巷已成为进行非物质文化旅游的常态场所, 并且已经成 为哈尔滨市文化旅游的标志, 实现了强大了品牌效应, 也为哈尔滨市非物质文化旅游开发积 累了经验。 


\section{2. 哈尔滨市非物质文化遗产旅游开发存在的问题}

\section{1 非物质文化旅游开发投入经费有限, 缺乏创新}

非物质文化遗产的整理、保护、宣传和旅游开发需要投入大量的财力和人力。目前、政 府部门每年都会有一定的资金支持，但因资金来源单一、数额有限还远远无法满足众多项目 的开发。以五常东北大鼓为例，其演出空间多分布在农村地区，演出价格较低且市场有限。 同时, 能够表演此种演出的剧团多为县级基层剧团, 财政供给率低, 演职人员工资待遇低, 演职人员流失严重。使得戏曲面貌陈旧，难以获得更好地传承和创新。

\section{2 非物质文化遗产面临着生存土壤丧失和后继乏人的局面}

适宜的社会经济、生态环境有利于非物质文化遗产的生存需要。随着城镇化进程的加快 及人们生活条件及思想认识的变化, 一些风俗习惯和文化生活已经有所改变, 非物质文化遗 产生存空间的压缩使其时刻面临着中断和失传的危险。例如, 许多身怀绝技的民间艺人都还 固有着 “传女不传男、传家不传外” 的旧思想, 使文化遗产遭到封存。做为满族传统体育项 目的珍珠球是哈尔滨市十大非遗项目之一，目前正面临着失传的危险。人们平时已经很少进 行这项体育项目, 现在只有在民族节日时才玩起这种运动。另一方面, 非物质文化遗产的传 承很大一部分是依靠口心授, 如其继承者在传承过程中缺乏归属感、认同感及历史感那很可 能造成此项遗产的消亡。方正剪纸种类繁多, 目前, 最具影响力的传承人叫倪秀梅, 随着剪 纸老艺人故去, 原有古朴稚拙、深厚粗犷的剪风本地型剪纸已基本消亡。为追求风尚, 某些 剪纸艺人的剪风让方正剪纸固有的风格大打折扣。

\section{3 开发比较零散, 缺少系统规划}

哈尔滨市非物质文化旅游开发的前提是系统、科学、合理的旅游规划。目前, 虽然在开发 中做了有益的尝试, 取得了一定的成果, 但由于缺乏系统的规划, 哈尔滨市非物质文化遗产因 其内部整合程度较低,开发比较零散。哈尔滨市非物质文化遗产的保护、开发、宣传和展演市 由文体局负责, 而旅游项目规划是由旅游局负责。这种现状在一定程度上限制了非物质文化 旅游的发展, 由于保护和开发归属两个部门, 所以在旅游规划、市场分析和项目开发可行性 论证方面会出现一些断层, 不利于从整体上一盘棋的进行旅游规划, 非物质文化旅游的开发 处于无序、自由的状态, 重复建设、盲目跟风现象频现, 大大降低了哈尔滨市非物质文化旅 游的价值和品位。

\section{4 对外宣传不到位}

哈尔滨历史悠久, 早在 22000 年前, 旧石器时代晚期就有人类活动, 曾是金、清两代王 朝的发祥地, 拥有丰富的人文旅游资源。地区旅游的重点一直集中于冰雪旅游、松江湿地、 避暑夏都、欧陆风情等方面。近年来, 哈尔滨市逐步重视文化旅游的发展, 但是从旅游形象 宣传的重点和旅游线路开发可以看出, 更加偏重于冰城夏都的自然特征的宣传, 及欧陆文化、 都市新貌、节庆会展等文化旅游的发展, 对以非物质文化的宣传仍然主要集中于文化部门, 旅游局的网站, 手机、网络、电视等大众媒体的推广和宣传较少, 宣传途径单一致使相关非 物质文化旅游活动的客源范围狭窄, 外地游客了解的极少。此外、非物质文化旅游在宣传过 程中也极少与景区、旅行社联合, 酒香也怕巷子深, 在很大方面也不利于非物质文化旅游的 开发。

\section{3. 哈尔滨市非物质文化遗产旅游开发的对策分析}

基于对哈尔滨市非物质文化旅游的现状和旅游价值评价, 结合哈尔滨市非物质文化遗产 的优劣式分析, 对于其旅游的开发, 更应做到有保障, 有计划、有步骤, 保护与旅游发展有 效互动, 提出如下发展对策。 


\section{1 不断完善哈尔滨市非物质文化旅游开发的保障机制}

\section{1 .1 完善政策保障机制}

随着《黑龙江省非物质文化遗产名录项目保护管理暂行规定》的出台，哈尔滨市非物质 文化遗产保护中心的成立, 已经使得哈尔滨市相关保护工作得到了长足的进展。在未来, 政 府应进一步出台相应政策, 完善志愿者机制和各类文化、技能培训机制, 畅通非物质文化遗 产保护与各类学术机构的沟通，发挥传统艺术表演团体、公共文化机构、文化艺术研究机构 和民间团体的作用。建立哈尔滨市非物质文化旅游管理机构，负责和监督哈尔滨市整体非物 质文化旅游项目的资源保护和开发工作。建立政府协调主导和社会参与共同发展的模式, 通 过非遗保护联席会制度，切实解决政策保障问题。

\subsection{2 积极拓宽融资渠道}

哈尔滨市非物质文化旅游项目的发展, 需要大量的资金, 在完成好项目可行性研究之后, 应鼓励国家和政府进行财政拨款，利用好政府公益性财政补助、专项基金等政策措施。推动 各类银行和地方金融机构增加对于旅游项目的基础设施建设。积极吸纳民间资本，进行非物 质文化遗产开发的社会化运作，政府负责建立投资项目库及投资指南，牵头完善高效、简明 的资金管理制度和项目审批程序，通过良好的项目投资效益分析进行招商引资，完善旅游项 目投资管理体系并实施监督管理。

\section{2 加强保护, 力求旅游发展 “长远化”}

传承人的发现和培养是非物质文化遗产保护的关键, 但现实的情况是很少有年轻人愿意 从事到非物质文化遗产的传承中。虽然国家会出资专项基金用于维持非物质文化的传承, 但 至今人才的流失还没有从根本上得以解决。此外非物质文化遗产的传承需要与它匹配的生存、 传承、发展的环境, 所以单一依靠输血式的保护, 一方面会增加政府财政的压力, 另一方面 也因其 “钱途” 渺茫而使继承者放弃。而对于非物质文化遗产的开发, 在为非物质文化遗产 传承提供资金的支持的同时，还可增强继承者的保护意识，同时通过对非物质文化旅游产品 的开发, 还会吸引社会上更多的有素质的爱好者参与其中, 以旅游为带动, 使非物质文化遗 产在获得动态继承的同时获得了保护。

\section{3 资源整合，做到旅游开发的 “规模化”}

哈尔滨市有着众多的非物质文化遗产资源，但因为各类资源的差异性及政府及旅游企业 的经济能力的限制, 单一的对一种非物质文化遗产进行旅游开发, 其对游客的吸引力都是有 限的。故将多种形式的非物质文化遗产加以整合, 有利于使旅游形成规模化, 增强旅游吸引 力。哈尔滨市的非物质文化遗产资源分布具有一定的地域集中性，主要集中在阿城、双城、 五常等几个区市, 因此, 结合哈尔滨市旅游已经打造 “中国・哈尔滨之夏国际文化旅游节” 城市品牌，“湿地节”、“啤酒节”、“哈夏音乐会”、哈洽会和地方系列节庆活动。通过， 建立非物质文化遗产展示中心，同时通过便捷的交通，将与各个分散、独立的资源有效地连 接起来, 建立规模宏大的哈尔滨市非物质文化遗产体验区, 这样既避免了非物质文化遗产的 迁移和复制, 保持了其原生态的特征, 同时也有利于促进当地的交通等基础设施建设, 促进 当地民俗、观光、乡村旅游的发展。围绕文化、冰雪、生态等旅游产品体系, 不断推出休闲 度假、体验性、娱乐性的旅游精品。哈尔滨市非物质文化遗产开发应当依附哈尔滨市特色的 物质文化遗存，打破单纯以城市风光旅游为主的旅游线路格局，全面打造城市风光、民俗风 情, 以非物质主体的吃、住、行、游、娱、购的非物质文化遗产主题旅游线路, 深入挖掘内 涵, 在游客获得偷悦的同时, 使物质和非物质文化遗产在同一空间相互促进、扩大影响。

\section{4 加强对外宣传力度, 做到营销手段 “创新化”}

目前，哈尔滨市非物质文化遗产保护中心先后进行了哈尔滨市首届非物质文化遗产代表 性项目展示暨授牌仪式活动; 参与哈尔滨市文化和新闻出版局主办、中心承办的哈尔滨市非 
物质文化遗产大图典首发式、优秀项目展示展演活动; 组织编纂了《哈尔滨市非物质文化遗 产名录图典》; 相继举办 “金源神龙杯” 满族传统莫勒真大会及黑土情愫. 黑龙江剪纸艺术 家作品展等活动。这些活动有效地丰富了非物质文化遗产的表现和传播形式, 增强了哈尔滨 市的文化吸引力。今后, 还应进一步结合哈尔滨市旅游发展要求, 积极发挥品牌效应, 通过 哈尔滨市特有的非物质文化资产资源的传播, 加强报刊、电视、网站等渠道的宣传力度, 吸 引更多的旅游者的到来，从而促进当地旅游业朝着健康方向发展。

通过哈尔滨市非物质文化保护中心，哈尔滨市旅游局、哈尔滨市文化广电新闻部门，以 及各大电视台、报纸等机构进行宣传, 及时更新相关内容, 让人们了解到保护和传承非物质 文化遗产的重要性, 了解各项活动的举办时间、地点。同时, 积极与旅游景区、酒店、旅行 社进行合作与宣传, 给予旅行社相应优惠折扣, 将部分旅游项目纳入的常规旅游线路中, 开 发非物质文化遗产专项旅游。

\section{5 不断发展促进传统文化 “博物馆化”}

开发博物馆模式是进行哈尔滨市非物质文化旅游开发的一种有效尝试。博物馆模式开发 可建立在社会结构、经济情况和精神生活及自然环境相对完整的文化生态中。哈尔滨市阿城 金源文化旅游区可以其具有浓厚的满族文化色彩，良好生态环境、非物质文化遗产聚集等特 点建立活态的博物馆, 向游客展示出能够体现完整、活态的经济、文化、环境完整的非物质 文化活标本。可将其建设成为满族民族文化的展示单位, 以让游客全方位的了解满族非物质 文化遗产的特色。目前, 哈尔滨市已经开发出了独特的公助民办办馆模式, 北方民艺精品馆、 大众肉联集团历史博物馆、哈尔滨艺术宫版画博物馆已经在进行非物质文化旅游开发和保护 过程张做了有效尝试并取得了一定的成绩, 在未来除了利用企业改制,引导行业办馆; 利用城 市改造,扶持民间办馆; 利用政策导向,倡导社会办馆, 还应在实践中形成更多的适于非物质文 化遗产旅游开发和保护的博物馆办馆模式。

\section{References}

[1] Ferdinand N., Williams N.L. International Festivals as Experience Production Systems,Tourism Management, vol.34,pp.202-210, 2013.

[2] Esteban Ruiz Ballesteros,Macarena Hernandez Ramirez, Identity and community the development of mining heritage tourism in Southern Spain, Tourism Management, vol.28,pp.677-687,2007.

[3] Susan O.Keitumetse, Sustainable Development and Cultural Heritage Management in Botswana : toward sustainable communities, Sustainable Developmen, vol. (5) ,pp.419-425, 2009.

[4] Zhu D M,General survey and protection of intangible cultural heritage in traditional medicine in Zhejiang Province, Zhonghua yi shi za zhi,vol.10,pp. 226-229,2017.

[5] Yafeng WANG, Zekun ZHOU, The Details Exploration of Intangible Cultural Heritage From the Perspective of Cultural Tourism Industry: A Case Study of Hohhot City in China, Canadian Social Science, vol.10.3968,pp.30-36,2016. 